\title{
THE MeANings Of THe PHILOSOPHY OF SymbOl Of THE PATUAEKKON TRADITION IN THE MANDAILING MUSLIM BATAKNESSE COMMUNITY ON THE NORTHERN BORDER OF WEST SUMATRA
}

\author{
Fitri Mawaddah ${ }^{1 *}$ \\ ${ }^{1}$ Institut Agama Islam Negeri Bukittinggi, West Sumatra, Indonesia, e-mail:fitrimawarddab@gmail.com \\ ${ }^{*}$ Corresponding Author

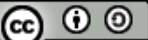

(C)2021 by the authors. Submitted for possible open access publication under the terms and conditions of the Creative Commons Attribution-ShareAlike 4.0 International License-(CC-BY-SA) (https://creativecommons.org/licenses/by-sa/4.0/) do) DOI : http://dx.doi.org/10.30983/it.v5i2.4893

\begin{tabular}{l|l|l} 
Received: 8 October 2021 & Revised: 16 December 2021 & Published: 31 December 2021
\end{tabular}

\begin{abstract}
This article aims to describe the meaning of symbolic philosophy contained in patuaekkon tradition at the wedding of Mandailing Batak Muslim community in Kampung Harapan Village, Pasaman Regency. This research article uses the field research method, in which the researcher collects data directly at the research location to strengthen the results of the philosophical meaning contained in patuaekkon tradition with a descriptive approach. The results of this study indicate that the meaning of symbolic philosophy of patuaekkon tradition consists of water symbolizing purity, kaffir lime symbolizing cleanliness, silunjuang leaves symbolizing self-adjustment, midrib leaf of banana stem and miracle leaves symbolizing peace and tranquility, nacar symbolizing the process of life's journey, ulos symbolizing blessing and affection, onang-onang song as an expression of joy, praise, hope, advice, and prayer. Poda has a meaning as advice in social life, ways to find a good and right livelihood, and habits in life.
\end{abstract}

Keywords: Philosophy of symbolic, Patuaekkon tradition, Mandailing community.

\begin{abstract}
Abstrak
Artikel ini bertujuan untuk, menguraikan makna filosofi simboik yang terkandung dalam tradisi patuakeon padapernikahan komunitas Muslim Batak. Mandailing Perbatasan utara di Kampung Harapan Kabupaten Pasaman. Penelitian artikel ini menggunakan metode field reasearch, dimana peneliti mengumpulkan datadata secara langsung di lokasi penelitian untuk memperkuat hasil makna filosofi yang terkandung dalam tradisi patuaekkon dengan pendekatan deskriptif. Hasil penelitian ini menunjukkan bahwa makna filosofi simbolik tradisi patuaekekon terdiri dari air melambangkan kesucian, jeruk purut melambangkan kebersiban, daun silunjuang melambangkan penyusaian diri, pelepab batang pisang dan daun cocor bebek melambangkan kedamaian dan ketentraman, nacar melambangkan proses perjalanan hidup, ulos sebagai makna restu dan kasih sayang, lagu onang-onang sebagai ungkapan kegembiraan, pujian, barapan, nasehat, dan do'a, poda memiliki makna sebagai nasehat dalam berkebidupan sosial, cara-cara mencari penghidupan yang baik dan benar, dan kebiasaan yang dilakukan dalam kehidupan.
\end{abstract}

Kata Kunci: Filosofi simbolik, Tradisi Patuaekekon, Masyarakat Mandailing

\section{Background}

In Mandailing Batak community, there are several events that are always followed by traditional ceremonies based on the traditional atmosphere. They are divided into two parts, namely: Batak traditional ceremonies in an

1 Abbas Pulungan, Daliban Na Tolu Peran dalam Proses Interaksi antara Nilai-nilai Adat dengan Islam Pada Masyarakat Mandailing dan Angkola Tapanuli Selatan, (Medan: Perdana Publishing, 2018), 122. atmosphere of mourning or what is called siluluton such as death, ${ }^{1}$ and Batak traditional ceremonies in an atmosphere of joy or what is called siriaon, such as: entering a new house, the birth of a child, and marriage. ${ }^{2}$

2 Sampur Dongan Simamora, Hakekat dan Manifestasi Dalihan Na Tolu Dalam masyarakat Adat Batak Toba, (Pontianak: FH Untan Press, 2012), 29-38. 
In the marriage tradition of Mandailing Batak Muslim community, there is a very monumental traditional event called patuaekkon. This event is an event of siriaon (joy) at horja Godang (traditional wedding party) which is held at the house of bayo pangoli (the groom). Patuaekekon tradition means the event of marudur (procession/parade) to tapian raya bangunan (a ritual to wash away the youth of the bride and groom) to perform the event of marpangir (potion bath) for the bride and groom. ${ }^{3}$

In patuaekkon tradition contains a philosophical meaning, namely that the bride and groom are bathed in a figurative sense for mangayup haposoan dohot habujingan (to wash away the youth). The goal is that both of them have to get rid of the traits and behaviors as teenagers, and place themselves as people who have become a group of parents because they are married. ${ }^{4}$

As the time goes by, Mandailing Batak people migrated to Kampung Harapan village to settle down. Kampung Harapan is located in Nagari Tanjung Betung area, Rao District, Pasaman Regency, West Sumatra. It is an area which has a Nagari government system that consists of several tribes such as Minang tribes as the majority, Batak Mandailing, Batak Toba and Java tribes who have their own tradition and culture. Even though they are in such environmental conditions, Mandailing Batak people who live in that area still survive and carry out their customs and tradition.

The fact that Mandailing Batak people in Kampung Harapan, Nagari Tanjung Betung still

3 Hamdani Al Rasyid Siregar, "Makna Simbol Upacara Adat Pabuat Boru Pada Masyarakat Batak Mandailing di Kabupaten Tapanuli Selatan Sumatera Utara", Jurnal: Jom Fisip 6, no. 2 (2019):4.

4 Deni Eva Masida Dalimunte, "Tor-Tor Pada Upacara Adat Perkawinan Masyarakat Tapanuli Selatan", Jurnal: Seni Sastra 1, no. 2 (2019): 8.

${ }^{5}$ Karimulla, (Trader, The Traditional Leader of Kampung Harapan Nagari Tj. Betung, South Rao District, Pasaman Regency) Interview, $\{20$ November 2020\}.

${ }^{6}$ Agustianto A. "Makna Simbol dalam Kebudayaan Manusia”, Jurnal Ilmu Budaya 8, no. 1 (2011): 1. carry out patuaekeon tradition is a cultural phenomenon that deserves to be investigated. It is because Mandailing Batak people still uphold their customs in the midst of a pluralistic society.

Although patuaek.kon tradition is still being carried out, it was found that most of the people do not understand the meaning of patuaekkon tradition. From the result of unstructured interviews with the local traditional leader, $\mathrm{Mr}$. Karimullah Harahap, he confirmed this. It was further explained that the practice of patuakkon was carried out because it was only to enliven the wedding procession and to be seen as respectful and authoritative by other people because they had been able to hold patuaekkon event. ${ }^{5}$ This lack of public understanding raises concerns about the fading of a culture ${ }^{6}$. Therefore, it is necessary to study and understand the philosophical meaning of patuaekkon tradition. As it should be, the practice of each tradition is carried out with full awareness, understanding and appreciation from each generation so that they know and understand every meaning in the tradition that is carried out.

Many previous studies explain the marriage tradition in Mandailing community. First, a study conducted by Akhiril Pane ${ }^{7}$ examines the tradition of mangupa in Mandailing cultural marriages. Second, Nenggih Susilowati ${ }^{8}$ studied about chewing betel leaf tradition and slaughtering a buffalo in Mandailing tradition. Next, Muslim Pohan' studied about clan marriage in Mandailing Batak community. And

7 Akhiril, Dkk, "The Performance of Mangupa Tradition in Angkola Cusum, Medan, Indonesia", Jurnal: Tazkir 5, no. 2 (2019): 235.

8 Nenggih Susilowati, "Tradisi Mangunyah Sirih dan Memotong Kerbau Pada Upacara Adat/ Horja di Angkola-Mandailing", Jurnal Berkala Arkeologi Sangkhala 2, no. 2 (2017):117.

${ }^{9}$ Muslim Pohan, "Perkawinan Semarga Masyarakat Batak Mandailing Migran di Yogyakarta”, Jurnal: Madaniyah 8, no. 2 (2018): 282. 
the last, Hafsah ${ }^{10}$ studied about the phenomenon of malangkahi marriage in Mandailing tradition.

In addition, some studies that explain the meaning contained in the marriage tradition of Mandailing community were carried out by several researchers. A study conducted by Hamdani ${ }^{11}$ researched the meaning of symbols contained in pabuat boru ceremony in Mandailing community. Mutiara ${ }^{12}$ examined the meaning contained in onang-onang melody. Aisyah ${ }^{13}$ researched the philosophy meaning in marriage.

From several studies conducted above, they generally focus on the procession of wedding traditions found in Mandailing community which explains the practice of these traditions. There are also researches that focus on the symbolic meaning contained in the marriage tradition of Mandailing community in general. However, the researches that highlight the philosophy meaning of patuaekeon tradition in marriages of Mandailing Batak Muslim community are still very limited. This study is different from the previous one because the study in this article explores the philosophy meaning contained in patuaekeon tradition which is included in Mandailing tradition marriage.

The method used in this study is field research which is a research by collecting data directly obtained from the research location. The type of research used is descriptive qualitative type. ${ }^{14}$ Therefore, the approach used in this paper is a semiotic approach, which is to reveal the meanings contained in a sign so that the researcher knows how the communicator conveys the message. ${ }^{15}$

10 Hafsah, "Fenomena Perkawinan Malangkahi dalam Adat Mandailing Natal Ditinjau Menurut Hulum Perkawinan Indonesia", Jurnal Almaslahah: Jurnal Hukum Islam dan Pranata Sosial Islam 9, no.1 (2021): 1.

${ }^{11}$ Hamdani Al Rasyid Siregar, , "Makna Simbol Upacara..., 1.

12 Mutiara Efendi Nasution, Tesis, "Analisis Sturuktur, makna, dan Melodi Onang-Onang Pada Adat Perkawinan Mandailing di Panyabungan", (UNSU, 2017), 1.
In order for the discussion under study to be more focused, the discussion that will be studied in this research is to explore more deeply the meaning of philosophy contained in patuaekeon tradition by revealing every meaning contained in each symbol used and the meaning of each language conveyed.

\section{Patuaekkon Tradition}

Besides washing away haposoan and babujingan (the youth period) from married couples, patuaekeon tradition is also an expression of joy from the groom's parents towards their son because their son has married to a good bride to be. As stated by Dalimunthe, "the practice of marriage in a traditional way is to announce that there has been a marriage between the bride and groom to the surrounding community. In addition, the practice of traditional marriage is carried out as a form of celebration and gratitude for marriage that has been legally valid in accordance with the religion and state which is offered by parents to their children. And also in the practice of traditional marriage, it is a unity in society which in its practice takes time and long preparations which can automatically strengthen the ties of brotherhood among Mandailing community."16

This patuaekeon event is also an event held in order to pray for the bride and groom to be given health, safety, and happiness by Allah SWT in carrying out married life and expelling evil spirits from their lives. Furthermore, with the practice of patuaekekon event, it is expected that they can achieve everything they want and their

13 Aisyah Ayu Musyafa, "Perkawinan dalam Persfektif Filosofi Hukum Islam" Jurnal Crepido 2, no. 2 (2020): 111.

14 Suharsimis Arikunto, Prosedur Penelitian Suatu Pendekatan dan Praktek, (Jakarta: Rineka Cipta, 2010), 310.

${ }^{15}$ Dian Aprila Diniarti, "Study of Semiotic Culture of Sasak Proverbs (Sesenggaq), Journal Lingua 14, no. 1 (2017), 15.

16 Al Maysita Dalimunthe,'Eksistensi Perkawinan pada Masyarakat Mandailing di Kota Medan", Jurnal Hukum dan Syari'ab 12, no. 2 (2020):198. 
goals. Socially, this event can elevate the family's dignity in the community.

The procedure for the practice of patuaekkon is carried out through several processions, starting from what must be prepared and until its practice. To find out a series of processions for the practice of patuaekkon tradition, the researcher conducted an interview with Mr. Baginda Mara Pardomuan Siregar about the series of processions for the practice of patuaekkon tradition. They are as the following:

"Sadari horja markumpul hatobangon dot harajaon marundingko gelar bayo pangoli, siap $i$ berangkat tu tapian raya bangunan diiringi gondang rap onangonang, moccak barisan anak boru na get marabi dalan. Sampe di si naik nacar, baru dipangir ma hadua penganten i mulai kan umak dot ayak ni bayo $i$, torus tu kahanggi, anak boru, hatobangon, hamaliman di tutup harajaon sambil mandokekon gelar ni bayo pangoli. mulak ma buse tu bagas godang. ${ }^{17}$,

"The day of the wedding ceremony, hatobangon and harajaon gather to discuss the name of harajaon to be given to the groom. Then go to tapian raya bangunan accompanied by onang-onang song and martial arts from the row of anak boru (the party from the groom side who will accept the bride). Then the bride and groom will go up nacar and will be bathed symbolically starting from the parents of the groom, then kahanggi, anak boru, hatobangon, hamaliman and finally closed with barajaon while reading the title of bayo pangoli (the groom)."

From the result of interview, the researcher can conclude that the practice of patuaekkon is carried out in several stages of procession, namely: mambaen goar (making a name) harajaon, onang-onang performance, marmoccake (anak boru martial arts), procession to tapian raya bangunan, and going up nacar.

Patuaekkon tradition which is a tradition carried out in pabuat boru event is carried out

${ }^{17}$ Baginda Mara Pardomuan Siregar, (Farmer, The Traditional Leader, The Player of Uning-uningan, South Tapanuli) Interview, \{12 June 2021). through several processions. As stated by Hamdani, the culmination of horja procession is at the men's house in the morning after the guests begin to arrive. Uning-uningan (gongs) are sounded to welcome the guests. Then it is continued with patuaekekon, which is to bring the bride and groom to tapian raya bangunan with marudur event (a procession/parade) to hold marpangir (potion bath) event. Then it is continued with malehen golar (giving the customary title). ${ }^{18}$

The following is the procession for the practice of patuaekeon tradition, including:

\section{Mambaen Goar (making a name) Harajaon}

The name of barajaon given to men, according to custom, is taken from the grandfather's name or the surname of the grandfather's level. The party who plays a role in giving goar harajaon to the groom is harajaon or namora-mora.

The name of harajaon for a newly married person will be given when the groom is at tapian raya bangunan (public bathing place). According to tradition, before a groom is given a name, Datu Parngongo has been doing meditation by being shrouded in traditional cloth at night. The purpose of the meditation is to ask for the presence of tondi Subut (the ancestor of the owner of the job/event) to dream. Therefore, during the traditional assembly at day, Datu Parngongo talks and asks Subut Sibabolonan about what he sees in the dream. The dream will be interpreted as a guide to naming. In front of Datu Parngongo, there is an ampang (basket) which contains silamoton (rice), chicken eggs, and areca nut. Sibut Sibabolonan replies that that night he had a dream of climbing a bayu ara tree (banyan) and mangala (catching) a lot of fish. This dream

18 Hamdani Al Rasyid Siregar, "Makna Simbol Upacara..., 5 . 
is interpreted as a sign that the name offered is good, which means it can be continued. ${ }^{19}$

The event of giving the customary title is conducted seriously. The customary title is usually taken from the names of their descendants. If the father has the title mangarajo, the child will be given the title sutan or baginda (king). If someone has an educational background and religious knowledge, his name will be added with the title tongku, such as Mangarajo Tongku. The title given to someone does not mean that he has to use it in everyday life. This title should only be used during traditional ceremonies. ${ }^{20}$

\section{Onang-onang Performance}

Onang in Mandailing language means singing. This definition does not generalize because song in Mandailing language is 'ende'. In the context of marriage, onang-onang is interpreted as a notice or an invitation to the audience and as an expression of what they feel. It is also as a song narration that describes the background of the owner of the event and the hopes that have been achieved and what will be desired in the future for the bride and groom and the whole family. $^{21}$

Onang-onang is a song with words as an expression of joy. Onang-onang is sung by a paronang-onang (a singer). The lyric of onang-onang does not have a definite text because onang-onang is created by paronang-onang spontaneously. Therefore, each paronang-onang must know in advance the purpose of the practice of traditional ceremony and to whom the onangonang is addressed. The contents of the onangonang consist of six kinds, namely: a) opening, b) explanation of the purpose of the ceremony, c) background story of the panortor, d) praise, e) advice, and f) prayer.

19 Hamdani Al Rasyid Siregar, "Makna Simbol Upacara..., 6.

${ }^{20}$ Abbas Pulungan, Dalihan Na Tolu..., 151.
As the result of interview conducted by the researcher with Mr. Baginda Mara Pardomuan Siregar as the paronang-onang (onangonang singer) regarding the contents of the onang-onang sung, are as follows.

"Onang-onag diendeon paronang-onang na tercipta spontan. Isi ende na disesuaikon kan latar belakang kehidupan si subut babolonan. Isi satiop onang-onang i pasti mulai kan pembukaan, tujuan ni horja, sejarah bidup ni na di horjaon, pujian, nasehat, dot do'a."22 "Onang-onang is sung by paronang-onang which is created spontaneously. The content of the song is adjusted to the background of subut babolonan. The contents of each onang-onang must start from the opening, the purpose of the party, the life history of party owner, praise, advice, and prayer.

From the result of the interview, it can be concluded that onang-onang is a song lyric that will be delivered at the horja (party) event which is included in patuaekkon tradition. The onang-onang is created spontaneously by the paronang-onang and usually the paronang-onang has got the data of the event owner. This data is very important because it will be told later in the lyric of onangonang about the background of the owner of the event and the purpose of the event.

In terms of the lyric, onang-onang text that expresses or tells while flattering various things related to the people who are conducting the event, the social status of the person who is the manortor (the dancer of tor-tor) as well as the condition of the location where the tor-tor is carried out, and contains the expression hope to get the good things in life such as good luck, the glory of the spirit of life and social solidarity. In the contents of the onang-onang lyric, there are also patterns used, namely the opening, explanation of the purpose of the ceremony, the

21 Tesisi, p. 175.

22 Baginda Mara Pardomuan Siregar, (Farmer, The Traditional Leader, The Player of Uning-uningan, South Tapanuli) Interview, \{12 June 2021). 
background story of panortor, praise, advice, and prayer.

\section{Marmoccak (Martial Arts of Anak Boru)}

Marmoccak is carried out by anak boru party when the bride and groom will be paraded to tapian raya bangunan. From the observation conducted by the researcher, marmoccak is a movement that resembles silat. The movement from marmoccak is mangarabi dalan (clearing the road) which is lush to get to tapian raya bangunan where haposoan and habujingan (the youth) of the bride will be washed away. The people who perform marmoccak will use the sword as a symbol of mangarabi (clearing). The anak boru will clear the road that will be passed by the bride of their mora (the party who gives the unmarried girl/the bride) to tapian raya bangunan so that it is not thick and dark by the weeds. ${ }^{23}$

As the result of an interview with $\mathrm{Mr}$. Mangaraja Lelo Dongoran that marmoccak is carried out by the front row of anak boru to clear the road in the figurative words. ${ }^{24}$ The row of anak boru will perform silat movements as if they are cutting down a lush road for the bride and groom to pass.

\section{Procession/Parade to Tapian Raya Bangunan}

The procession/parade is a process towards tapian raya bangunan. The procession is carried out in small steps. The bride and groom will be di togu (accompanied) by anak boru. In the procession, it will be accompanied by onang-onang and their gondang (gongs). In front of the bride and groom, there will also be people who perform marmoccak (silat) from anak boru party. ${ }^{25}$

To clarify how the procession goes to tapian raya bangunan, the researcher conducted interview with traditional leader, namely $\mathrm{Mr}$. Mangaraja Lelo Dongoran, as follows:

\footnotetext{
${ }^{23}$ Observation, Kampung Harapan, 6 June 2021.

${ }^{24}$ Mangaraja Lelo Dongoran, (Farmers, Traditional Kings), Interview, $\{21-22$ June 2021\}.

25 Sutan Tinggi Berani Perkasa Alam, Pembaharuan dan Modernisasi Adat Budaya Tapanuli Selatan Adat Hombr
}

" Arak-arakan i sebenarna na paboaon tu balak na bahat bahwa anak nalai i ma sab menikah ima dot adaboru na di buat nalai na jadi parumaen nalai. Kedua penganten i ditogu sian barisan anak boru sebagai rasa senangnya bati di pernikahan nalai." ${ }^{126}$

(This procession/parade is actually to inform the public that their child has married the woman they picked up as their daughter-in-law. The bride and groom will be di togu (accompanied) by anak boru (the sister of groom's father's/the groom party) who tell them how happy they are about their marriage).

From the result of the interview, it can be seen that in the procession of the bride and groom is ditogu (accompanied) by the row of anak boru. Pangir (kaffir lime and silunjuang leaves for bathing) is carried by anak boru and marmoccak is also performed by anak boru. Therefore, in this event anak boru play many roles.

Anak boru in Batak community is the one who takes namboru and iboto. Namboru in every event conducted by mora, they will always be ready to do anything that will be required by mora. In other words, anak boru is a person who works in the kitchen and prepares everything so that a traditional party that is held runs well. The position of anak boru is a position that must be ready to serve, guard, and protect their mora from everything. The roles of anak boru towards mora are as follows:

a. Tukkot di landit, means stick on slippery roads. Anak boru is a support for their mora's life.

b. Sulu dinagolap, means a torch in the dark night. Anak boru in his position acts as a torch, as a lamp that always provides light for their mora so that their mora does not get lost.

c. Na juljul tu jolo, artiya is willing to open and pave the way. Anak boru is a guide and protector for their mora.

Dohot Adat Ibadat dalam Pelaksanaan, (Padangsidimpuan: TP, 2005), 15.

${ }^{26}$ Mangaraja Lelo Dongoran, (Farmer, Traditional King) Interview, \{21-22 June 2021\}. 
d. Nagogo manjunjung, means the strong support. Anak boru has strong principles to assert their mora so that they become people who are respected, happy and have wealth. Because if their mora are respected, anak boru also feel it too.

e. Goruk-goruk hapinis, means a locking device or a very strong wooden fence. It means that anak boru act as guards and protectors who are always ready at any time for the benefit of their mora.

f. Sitamba na burang Siborus nalobi, means the one who adds to the shortage and the one who takes the excess. In every event, whether it's siriaon or siluluton, anak boru is ready to add to all deficiencies and if there is excess, they have the right to take it. ${ }^{27}$

Therefore, in patuaekkon event, the role of anak boru in the practice is quite a lot. The role of anak boru is here to protect the child of their mora as a sense of submission to their mora. From the start, anak boru are the people who accompany, bring pangir and perform marmoccak.

\section{Going up Nacar}

Nacar is a building that is in tapian raya bangunan. Nacar is a place where the bride and groom are bathed symbolically by sprinkling a potion to wash away the youth. Nacar has 3, 5, or 7 stairs as many as pangupa which is slaughtered. The first person to go up nacar is boru na di oli (the bride) then bayo na di oli (the groom). After the bride and groom sit on the nacar, then they will be bathed symbolically, by being sprinkled with mixed pangir.

As conveyed by Mr. Baginda, at nacar the bride will be bathed symbolically by being sprinkled with water seven times by saying $1,2,3,4,5,6,7$ including advice, hope, and prayer

27 M Dalimunte, Tesis, "Tutur Masyarakat Adat Batak”, (Medan: UIN Sumatera Utara, 2010), 12.

${ }_{28}$ Mara Pardomuan Siregar, (Farmer, Traditional Leader, South Tapanuli Uningan player) Interview, \{21 June $2021\}$.

29 Nuriza Dora, 'kajian Kearifan Lokal Tradisi Marsattan/Mangupa (Meminta Keselamatan) pada for the bride and groom. It is ended by saying 'Horas! Horas! Horas!' which is the blessing word in Batak language. ${ }^{28}$

However, it can be understood that the way to bathe the bride is done variously depending on the person who sprinkles the pangir. What must be said while sprinkling the pangir is one, two, three, four, five, six, seven, seven generations away from all harm, Horas! Horas! Horas! And will be more fully complete by including words of advice, hope, and prayer.

According to Nuriza Dora, in the practice of custom of Mandailing community, especially in the practice of traditional ceremonies, prayers are inserted as a form of request to God Almighty to be kept away from danger in carrying out life. ${ }^{29}$ According to Pohak, et al., there are three basic values that are reflected in the practice of traditional ceremonies of Mandialing community, namely brotherhood, respect, and responsibility. ${ }^{30}$

\section{The Meaning of Symbolic Philosophy of Patuaekkon Tradition}

Patuaekkon tradition embodies the values of the philosophy of life. Each symbol that exists in terms of equipment used in the event will have its own philosophical meaning. The equipment used in patuaekon tradition and also its philosophical meanings include:

\section{Kaffir lime as a symbol of perfection}

Kaffir lime with its round shape symbolizes perfection. This teaches us to believe that in this life there is wheel of life. In addition, kaffir lime also symbolizes sustenance and luck. It is expected that the bride and groom will be given offspring and also abundant sustenance as many as the fruits of kaffir lime trees. Kaffir lime also

Masyarakat Mandailing Desa Gunung Melintang Kecamatan Barumun Tengah Kabupaten Padang Lawas", Ijtimaiyah Jurnal Ilmu Sosial dan Budaya 4, no. 1 (2020): 78.

${ }^{30}$ Haksa Romatua Pohan, Dkk, "Moral Values in Margondang of Angkola Ethnic", AICLL (Annual International Conference on Language And Literarure 3, no. 1, (2020): 75 . 
symbolizes the tastes in life which are sweet, bitter, sour, and so on. Furthermore, kaffir lime also has a distinctive aroma that can be used to remove the fishy odor. This symbolizes as a cleanser. By having cleaned using kaffir lime juice, the bride and groom are expected to be clean from all that is smelly and bad so that they are clean physically and mentally from everything that is not good.

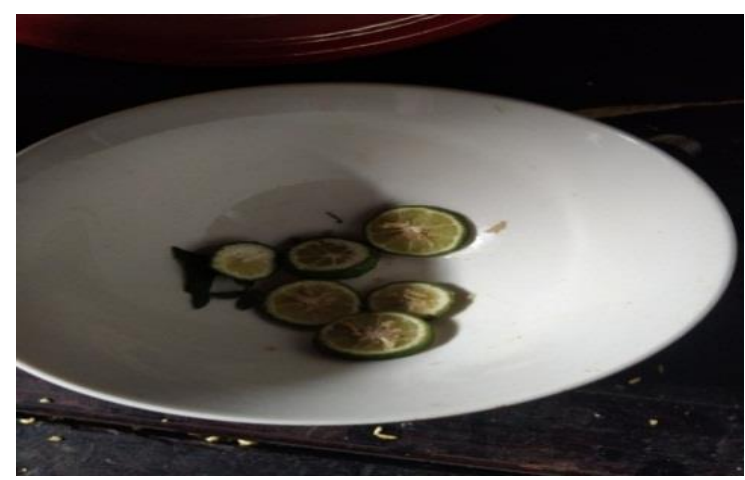

Figure 1: Kaffir lime

Kaffir lime is a form of nonverbal communication which is a sign to cleanse oneself from smelly things physically and spiritually. Another meaning of this kaffir lime, seen from the semiotic theory, is as the meaning of expressing hope and prayer for the bride and groom so that they will be given a lot of sustenance.

Silunjuang leaves (sipilit leaves, hatunggal leaves, and sanggul leaves) as the basis of social life

Silunjuang leaves which consist of sipilit leaves, hatunggal leaves, and sanggul leaves. They are green leaves symbolizing adaptation. Just like a leaf that is good at adapting to the weather and so do the bride and groom who are sprinkled by a splash of silunjuang leaf. They are expected to be able to adjust to married life which already has duties and obligations as well as binding rules. It also symbolizes prayer so that they grow well like the green leaves. The leaves are also usually planted on the land border as the boundary. It means in married life there are also boundaries that they must keep. The bride and groom are no longer allowed to freely associate with other people, especially the opposite sex. It will cause quarrels in married life. Therefore, it is expected that after being sprinkled with water of silunjuang leaves, they can adjust and place themselves in all conditions wherever they are and can be relied on.

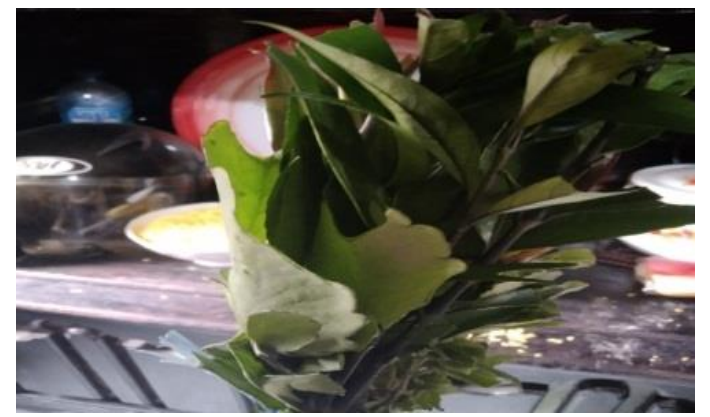

Figure 2: Sipilit Leaf

Thus, it is expected they can obey the rules that exist in a family or in a household. They have to realize that they are no longer teenagers who live separately and alone, but they are already bound by marriage. These silinjuang leaves mean as a sign that the bride and groom can adjust to each other in married life because they are already bound by some boundaries.

\section{Yellow rice as a symbol of prosperity}

Yellow rice means fertility, prosperity and harmony in married life. This yellow rice is a mixture of rice with a yellow color made from artificial coloring or turmeric. The hard rice and the yellow mixture of turmeric have meaning that the souls of the bride and groom are as strong as the rice so that they get a life of bamoraon, hagabeon, and hasangapon (wealth, success, and glory) in married life.

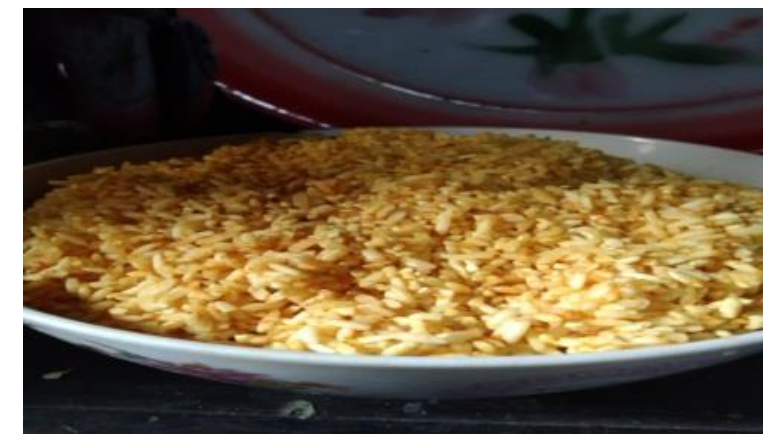

Figure 3: Yellow Rice

Yellow rice means verbal communication which wants to be conveyed that later after this marriage they are active in work so that they gain 
wealth by achieving success in order to be respected by others.

Midrib leaves of Banana stems and Miracle leaves (Kalanchoe Pinnata) as symbols of peaceful life

The midrib leaf of banana stem and miracle leaves have meaning of peace and tranquility. If the midrib leaf of banana stem and miracle leaves are held with hands, they will feel cold and create a sense of peace and serenity. The texture of these two objects that creates a sense of coolness is also expected to provide coolness for those who are married so that their married life is always in a peaceful life.

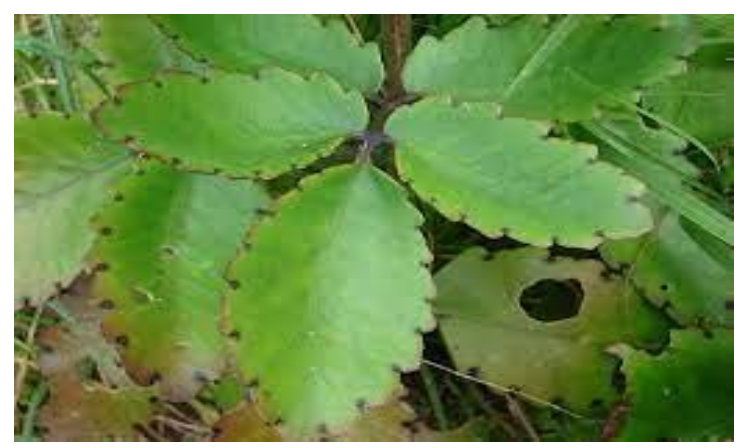

Figure 4: Miracle Leaves (Kalanchoe Pinnata)

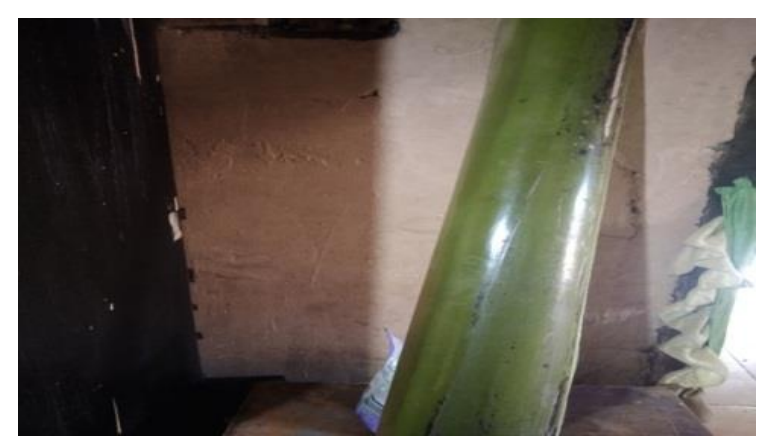

Figure 5: Midrib leaf of Banana Stem

The midrib leaf of banana stem and the miracle leaves have meaning as an expression for the bride and groom to live in peace and in a peaceful life.

\section{Nacar As a Symbol of Life Process}

Nacar is a building that has stairs made to fit two people. This nacar is the place where the bride and groom will be bathed using potion that has been made with predetermined ingredients.

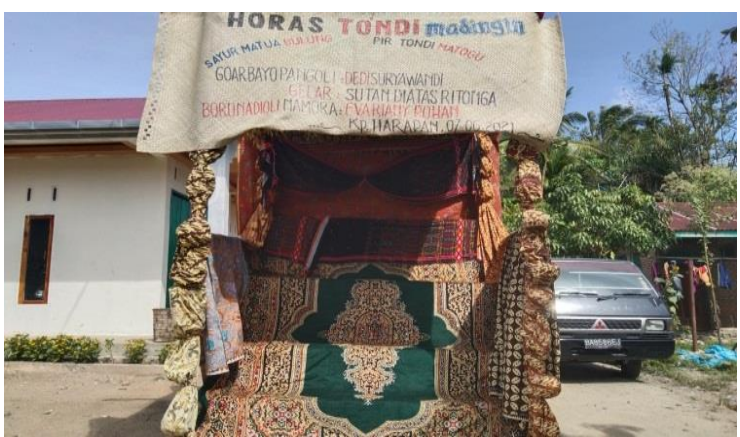

Figure 6: Nacar

Nacar symbolizes the process in life that is expected to reach the peak of true life both in terms of descent, sustenance, and worship which is always increasing. Nacar which has stairs symbolizes that it is a process in life to achieve success. If you are patient through the process of the ladder of life, you will get to the top, namely success. If you are impatient with every process that occurs, you can slip and even fall which results in destruction.

\section{Ulos Batake as a Holong Symbol}

Ulos Batak symbolizes blessing, affection, unity and a symbol of communication for Batak indigenous people, in accordance with the Batak proverb which reads "ijuk pangihot ni hodong, Ulos pangihot ni holong" which means if the palm fiber binds the midrib on the stem then Ulos is as a binder of affection between each other.

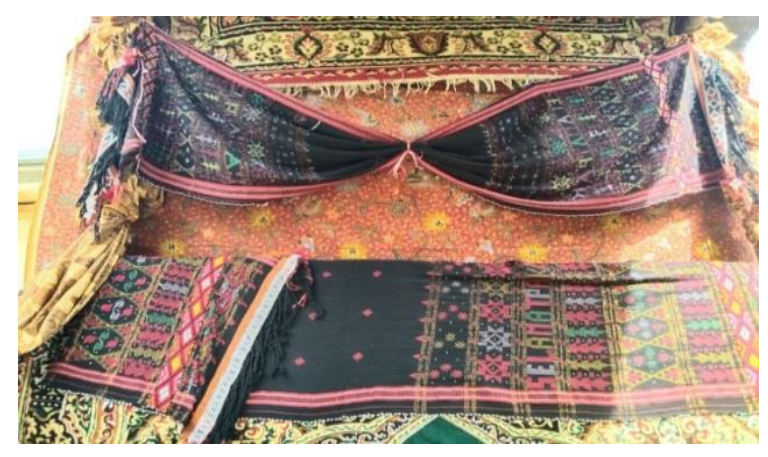

Figure 7: Ulos Batak

From the equipment used, nacar and Ulos Batak, have a meaning as communication conveying that all things in this life require a process. Like nacar which is in tapian raya bangunan, we have to go up several stairs in order to reach the top level as a place to sit. As well as in life, there is a ladder that must be passed in 
obtaining success that is rare. Step by step until we reach its peak through that ladder. Furthermore, focus and consistency are needed in order to achieve the success. Focus and consistency are symbolized by the glasses. Moreover, achieving success cannot be separated from the help of others because living in this world we need each other. We cannot live alone which is symbolized by Ulos Batak as a reminder that there is unity where we can get love.

\section{Semiotic Analysis on Onang-onang Lyric}

Semiotics etymologically comes from the Greek word semeion which means "sign" (sign), has function as sign and production of meaning. ${ }^{31}$ As for terminology, semiotics is a branch of science that deals with the study of signs and everything related to signs, such as sign systems and processes that apply to signs. Semiotics is a science that studies a wide range of objects, events, and all cultures as signs. ${ }^{32}$

A sign is something that has another meaning to others. Anything that can be observed or made observable can be called a sign. The presence of an event, the absence of an event, the structure found in something, or a habit, all of them can be called a sign.

Semiotics is a theory that emphasizes the reader's aspect, namely the reading of heuristics and hermeneutics. The reading of heuristic is reading based on language structure, while reading of hermeneutic is reading based on giving meaning or interpretation of the text. The meaning or interpretation is often expressed by means of a metaphor, namely seeing something through another object. ${ }^{33}$

In a semiotic metaphorical way, the text onang-onang is full of depictions or descriptions relating to aspects of the life of the presenter.

31 Ambarini, Nazla Maharani Umaya, Semiotika Teori dan Aplikasi Pada Karya Sastra, (Semarang: IKIP PGRI Semarang Press, Th), 27.

${ }^{32}$ Dian Aprila Diniarti, "Kajian Semiotik Kultural Peribahasa (Sesenggaq) Sasak", Jurnal Lingua 14, no. 1 (2017):10.
Both aspects related to personal life of the party owner, backgrounds, advice, or hopes that are expressed in the form of heuristics or hermeneutics.

Opening as a Sign of Mangido to Ask Permission to Open the Event

The lyric of onang-onang in the opening section uses lyric that explains how this event will begin. The onang-onang lyric in the opening section is:

"Ile onang baya onang, Tapuka ma le tajolo ta mulai on, Mada asok ma jolo le fikiri ada, Ulang mada maruba nian ale luai on, Sian na jolo indun mada sannari on. Santabi mada sappulo on, Sappulo noli marsattabi on, Lobi na da tarpasangapi on, Ois ind taronang ale baya onang. ${ }^{34}$ (Ile onang baya onang, Let's start this opening first, Slowly we think, Don't let anything change, From the past until now. We apologize to all the kinsman and audience, especially to the respected ones, Ois mada taronang ale baya onang).

From the lyric of the onang-onang in the opening, it means asking for permission to immediately start the event. The words Santabi mada sappulo on, Sappulo noli marsattabi on, Lobi na da tarpasangapi on are expressions of giving respects to the relatives, hatobagano, the traditional king, especially subut who is holding a party and that the singer will ask permission to start event with respect.

Explanation of the Purpose of the Ceremony as the Background of the Event

The onang-onang section which explains the purpose of this ceremony contains lyric which means that an event is held for a reason, or explains the background of this event being held. The lyric of onang-onang in the explanation of the purpose of the ceremony is:

33 Henry Guntur Tarigan, Pengajaran Semantik, (Bandung: Angkasa, 1995), 112.

34 Baginda Mara Pardomuan Siregar, (Farmer, Traditional Leader, South Tapanuli, Uningan Player) Interview, \{21 June 2021\}. 
" Ile baya onang-onang, On ma hape niat ti, Haroro ni da paronang parumaen on, parumaen siakkaan on, I ma na palalu baga-baga on. ${ }^{135}$

(This is our intention. Welcoming the arrival of our daughter-in-law. This eldest daughter-in-law. This is as the implementation of intention (borja patuaekkon).

The onang-onang lyric in the explanation of the meaning of the ceremony is as the reason for the patuaek.kon party being held by the groom's parents. In the lyric, it is said that the practice of the event is the intention of groom's mother to hold a borja godang to welcome her daughter-inlaw's arrival with delighted feeling and also brings joy to them as well as to their son. This is an expression of love for the son and daughterin-law.

\section{Panortor's Background Story (The dancer's background} story)

Panortor's background story is the part that explains the origin of the party. The lyric for the Panortor's background story is as follows:

"onma inanta ma da soripada i. Na ro sian dolok saribu on, On mada le mada mora nami on, $\mathrm{Na}$ maroban holong ni roba, On ma hape jolo ibana on, Harahap sarjana ma Dokter on, Na moroban le hasonangan on, Di haroro le parumaen o,." 36

(Dear mother, Who comes from the land of karo. This is our mora, Who brings joy to the heart, This is what she used to be, Harahap a scholar, Who has carried out this joy, Here comes her daughter-in-law

The lyric of the onang-onang song in the panortor's background story section is a story of the life journey of those who held a party, both the groom's parents and the bride's parents. Then, the journey of their child is being reunited which brings joy to them. This lyric means to always remember the story of life and the journey of life that is passed because it provides

${ }^{35}$ Mara Pardomuan Siregar, (Farmer, Traditional Teader, South Tapanuli, Uningan player) Interview, ( 21 June 2021\}. a very valuable lesson, always remember the origins of where we are from.

\section{Praise As a Sign of Joy}

The onang-onang in the praise section is the lyric that is created to convey the joy of the family of bayo pangoli (the groom) welcoming the arrival of their daughter -in-law.

The lyric in this praise section goes to boru na di oli (the bride). This is a compliment given from the husband's family to the wife's personality of their son. Tanda maho inang mada sori pada, Inang na malo mada maroroti, Namalo baya sumput ilung $i$, is a compliment given to the daughter-in-law they pick up. Tanda maho inang mada sori pada (You look like a good wife) this means baro na di oli (the bride) has good personality. This personality is usually seen from their family life and her behavior when she was a girl. Inang na malo mada maroroti (A mother who is good at raising children), implies that boru na di oli who has become their son's wife and also her daughter-in-law is graceful. Namalo baya sumput ilung $i$ (the wise in the family), means the wisdom in boru na in oli (the bride). Although she is graceful, she is wise in taking action.

Advice as Words of Warning

The lyric of the onang-onang in the advice section is the lyric that aims to convey words of advice and warning to the bride and groom in living a married life. The lyric of the onang-onang in the advice section is:

"Ile onang baya onang, Habang mada jolo si borkoopon, Songgop tu aek dorason, Muda babis munu amang ale manortoron, Inda lupa mandokekon horas on, Horas manian ale madingin, Anso pir tondi munu le madingini. Satabi hamu sa oloan, Sa lumpat sa indegean, Pas songon si ali sampogul, Rap tuginjang rap tu toru, Muda madabu rap madabu, Muda marbustak rap marbustak."

${ }^{36}$ Mara Pardomuan Siregar, (Farmer, Traditional Leader, South Tapanuli, Uningan Player) Interview, ( 21 June 2021\}. 
(Ile onang baya onang, First fly this mosquito, Stop by from this rushing water, When you are done dancing tor tor, Don't forget to pray and give thanks, So that the body will still be safe, So that you can have a strong soul and spirit. Agree to each other and always be united. Always be together in good and bad condition).

The onang-onang lyric in the advice section means to always pray and say gratitude every time you finish doing something. By always being grateful in every work done, our efforts will be safe and blessed by Allah so that our souls will be calm, enthusiastic and strong. Furthermore, meaningful advice is to live in deliberation with a wife/husband because it is one of the keys to success in marriage. Always talk about everything so that there is no misunderstanding later.

The lyric of the song onang-onang in the advice section is analyzed using semiotics, which is a verbal communication that has the meaning to always give thanks in every work done in order to get the blessing of Allah the Almighty. The symbol contained in this activity is in the form of language symbol which is conveyed in the form of lyric in the onang-onang which has meaning as advice to always live together and live in deliberation in every decision taken.

\section{Prayer as a Sign of Hope}

The lyric of the onang-onang in this prayer section is the lyric that contains hope and also a desire to Allah SWT to bless their marriage. The lyric of the onang-onang in the prayer section is:

"Tle onang baya onang, Anggo muppat ale padang ale tobuon, Mangibut siptogu ale dalani, Hupangidoon dobo baya nikku tutubani, Ulang be jolo le dong halangan nai, Akke madung rodo parumaen non, Parumaen ale baya si akekaanon, Ison au ale baya mandoaaon, Anso lolot bita jolo baya mangolui. "'37

(Ile onanag baya onanag, If this weed is uprooted, Following all that grows on the

37 Baginda Mara Pardomuan Siregar, (Farmer, Traditional Leader, South Tapanuli, Uningan Player) Interview, \{21 June 2021\}. road, I ask to God, So that there are no obstacles, For this daughter-in-law has come, daughter-in-law of this eldest child, On my side I pray for her, So that we can live longer).

The lyric of the onang-onang song in the prayer section contains hope to God Almighty, Allah SWT, to always give a long life to all who attend the event. And with the arrival of their daughter-in-law to their house, she is expected to bring blessings to the whole household.

The lyric of onang-onang in the prayer section is analyzed with the theory of semiotic philosophy, which is a communication that wants to convey a hope and desire. Analyzed using semiotic theory, it means verbal communication to live in harmony and love each other and be blessed with offspring.

\section{Conclusion}

Based on the result of research conducted in Nagari Tanjung Betung, South Rao District, Pasaman, West Sumatra with research on the meaning of the symbolic philosophy of patuaekkon tradition, it can be concluded several things as follows: First, Patuaekekon is an event of siriaon (joy) at the event of pabuat boru (wedding) which is held at the house of bayo pangoli (the groom) as a sense of joy for their son's marriage. Because of the incomparable sense of joy, Horja Godang is carried out, namely patuaekekon to wash away the youth of the bride and groom in Tapian Raya Bangunan. The procedures for the practice of patuaekkon are: panite dot manjagit boru (waiting and welcoming the bride), martahi godang (major discussion), markuras, mambaen goar, onangonang performance, marmoccak (Anak boru perform silat), procession/parade to tapian raya bangunan, and going up nacar. Patuaekkon is carried out by bathing the bride and groom in tapian raya bangunan by sprinkling pangir water made from a mixture of kaffir lime, silunjuang 
leaves, namely sipilit, hatunggal, and sanggul leaves mixed with enough water. The water is sprinkled with a bunch of silunjuang leaves tied to the midrib leaf of a banana stem.

The second, in the practice of patuaekkon contains the meaning of a deep philosophy of life contained in the symbols used in the practice of patuaekeon tradition. The meanings of the symbols in patuaekeon tradition are: 1) water symbolizes purity, 2) kaffir lime symbolizes cleanliness, 3) silunjuang leaves symbolize selfadjustment, 4) midrib leaf of banana stem and miracle leaves symbolize peace and tranquility, 5) nacar symbolizes the journey of life, 6) glasses symbolize focus and consistency, 7) Ulos symbolizes the meaning of blessing and affection, and 8) onang-onang song as an expression of joy, praise, hope, advice, and prayer.

\section{References}

Agustianto A. "Makna Simbol dalam Kebudayaan Manusia". Jurnal Ilmu Budaya. 8, no. 1 (2011).

Akhiril. Dkk. 2019. "The Performance of Mangupa Tradition in Angkola Cusum, Medan, Indonesia”. Jurnal: Tarkir 5, no. 2 (2019).

Alam, Sutan Tinggi Berani Perkasa. 2005. Pembaharuan dan Modernisasi Adat Budaya Tapanuli Selatan Adat Hombr Dohot Adat Ibadat dalam Pelaksanaan. Padang Sidempuan: TP.

Ambarini., dan Nazla Maharani Umaya. Semiotika Teori dan Aplikasi Pada Karya Sastra. Semarang: IKIP PGRI Semarang Press, Th.

Arikunto, Suharsimis Prosedur Penelitian Suatu Pendekatan dan Praktek. Jakarta: Rineka Cipta, 2010.

Dalimunte, Deni Eva Masida. "Tor-Tor pada Upacara Adat Perkawinan Masyarakat Tapanuli Selata". Jumal: Seni Sastra 1. no. 2 (2019).
Dalimunthe, M. "Eksistensi Perkawinan Pada Masyarakat Mandailing di Kota Medan". Jurnal Hukum dan Syari'ah 12, no. 2 (2020).

Diniarti, Dian Aprila. "Kajian Semiotik Kultural Peribahasa (Sesenggaq) Sasak". Jurnal Lingua 14, no. 1 (2007).

Dora, Nuriza. "Kajian Kearifan Lokal Tradisi Marsattan/ Mangupa (Meminta Keselamatan) Pada Masyarakat mandailing Desa Gunung Melintang Kecamatan Barumun Tengah Kabupaten Padang Lawas". Ijtimaiyah Jurnal Ilmu Sosial dan Budaya 4, no. 1 (2020).

Feriera, Rulia. Skiripsi: "Pergeseran Norma Larangan Pernikahan Satu Marga (Studi Etnografis Adat Batak Mandailing di Kecamatan Barumus Kabupaten Padang Lawas Sumatera Utara). Jakarta: UIN Syarif Hidayatullah, 2018.

Hafsah. "Fenomena Perkawinan Malangkahi dalam Adat Mandailing Natal ditinjau Menurut Hulum Perkawinan Indonesia". Jurnal Almaslabah: Jurnal Hukum Islam dan Pranata Sosial Islam 9, no.1 (2021).

Hamzah, Ali. "Pelaksanaan Adat Margondang Pada Pesta Pernikahan: Pergumalan Antara Nilai Luhur Budaya dan Tuntutan Pragmatis". Jurnal Hukum dan Syari'ab 12, no. 2 (2020).

Harahap, Nanda Fitri Herliani. Skripsi: “makna tradisi mangulosi pada pernikahan komunitas batak toba (di Desa Kampung Jering Kecamatan Bakauhenu Kabupaten Lampung Selatan)". Lampung: UIN Raden Intan, 2017.

M Dalimunte. 2010. Tesis. "Tutur Masyarakat Adat Batak". Medan: UIN Sumatera Utara.

Malik,"Zul. Skiripsi: 2019. (Tradisi Mangupa Labiran Daganak (Kelabiran Anak) Pada Masyarakat Batak Mandailing Di Kampung Pencin, Desa Sikijang, Kecamatan Tapung Hilir, Kabupaten Kampar, Provisi Riau)", Yogyakarta: UIN Sunan Kalijaga,

Musyafa, Aisyah Ayu. 2020. "Perkawinan dalam Persfektif Filosofi Hukum Islam". Jurnal Crepido 2, no. 2 (2020). 
Nasution, Kharisma. "Pemajemukan dalam Bahasa Mandailing. Jurnal Ilmiah Bahasa dan Sastra 2, no. 2 (2005).

Nasution, Mutiara Efendi. Tesis. "Analisis Sturuktur, makna, dan Melodi OnangOnang pada Adat Perkawinan Mandailing di Panyabungan".UNSU.

Pohan, Haksa Romatua. "Moral Values in Margondang of Angkola Ethnic". AICLL (Annual International Conference on Language And Literarure 3. no. 1 (2020).

Pohan, Muslim. "Perkawinan Semarga Masyarakat Batak Mandailing Migran di Yogyakarta". Jurnal: Madaniyah 8, no. 2, (2018).

Pulungan, Abbas. Dalihan Na Tolu Peran dalam Proses Interaksi antara Nilai-nilai Adat dengan Islam Pada Masyarakat Mandailing dan Angkola Tapanuli Selatan. Medan: Perdana Publishing. 2018.

Pulungan, Abbas. Dalihan Na Tolu Peran dalam Proses Interaksi Antara Nilai-nilai Adat dengan Islam Pada Masyarakat Mandailing dan Angkola Tapanuli Selatan. Medan: Perdana Publishing, 2018.
Radam, Noerid Haloei. Religi Orang Bukit. Yogyakarta: Semesta, 2001.

Simamora, Sampur Dongan. 2012.Hakekat dan Manifestasi Daliban $\mathrm{Na}$ Tolu dalam masyarakat Adat Batak Toba. Pontianak: FH Untan Press.

Siregar, Hamdani Al Rasyid. "Makna Simbol Upacara Adat Pabuat Boru Pada Masyarakat Batak Mandailing di Kabupaten Tapanuli Selatan Sumatera Utara". Jurnal: Jom Fisip 6, no. 2 (2019).

Wijaya, Bambang, dan Elmisyah Nur. "Semiotika dalam Metode Penelitian Komunikasi". Jurnal Penelitian Komunikasi, Informatika an Media Massa-Pekommas 16, no.1 (2013).

\section{Interviews}

Baginda Mara Pardomuan Siregar, (Farmer, Traditional Leader, Uning-uningan Player) Tapsel) Interview, \{21 Juni 2021\}.

Karimulla, (The traditional Leader of Kampung Harapan Nagari Tj. Betung, South Rao District, Pasaman Regency) Interview, \{ 20 November 2020\}.

Dongoran Mangaraja Lelo, (Farmer, the king of tribe) Interview, $\{21-22$ June 2021$\}$. 
